\title{
Intercultural Relations in Finland
}

\section{Brylka, Asteria Anna}

Cambrigde University Press

2017

Brylka , A A , Jasinskaja-Lahti , I \& Renvik (Mähönen) , T A 2017 , Intercultural Relations in

Finland . in J W Berry (ed.), Mutual Intercultural Relations . Cambrigde University Press,

Cambridge, University printing house , pp. 105-124 . https://doi.org/10.1017/9781316875032.005

http://hdl.handle.net/10138/234344

https://doi.org/10.1017/9781316875032.005

acceptedVersion

Downloaded from Helda, University of Helsinki institutional repository.

This is an electronic reprint of the original article.

This reprint may differ from the original in pagination and typographic detail.

Please cite the original version. 
Brylka,, A., Jasinskaja-Lahti, I., \& Renvik, T. (2017). Intercultural Relations in Finland. In J. Berry (Ed.), Mutual Intercultural Relations (Culture and Psychology, pp. 81-104). Cambridge: Cambridge University Press. doi:10.1017/9781316875032.005

\section{Intercultural Relations in Finland}

Asteria Brylka ${ }^{1,2 \dagger}$, Inga Jasinskaja-Lahti ${ }^{1 *}, \&$ Tuuli Anna Mähönen ${ }^{3}$

${ }^{1}$ Department of Social Research

University of Helsinki

POB 54 (Unioninkatu 37)

00014 Helsinki

Finland

${ }^{2}$ Institute for Social Innovation and Impact

University of Northampton

Innovation Centre

Green Street

Northampton

NN1 1SY

United Kingdom

${ }^{3}$ Open University

University of Helsinki

POB 9 (Siltavuorenpenger 3 A)

00014 Helsinki

Finland

$\dagger$ At the time of the MIRIPS-FI project the author was associated with the University of Helsinki.

Acknowledgements

We would like to thank Emma Nortio and Elena Waschinski (Department of Social Psychology, University of Helsinki, Finland) for their help in data collection and coding.

Funding

This research was funded by the KONE Foundation [grant number 31-219]. 


\section{Introduction}

With growing globalization and migration, research on intergroup relations in ethnoculturally diverse societies has become a world-wide scientific endeavor. This is mainly because challenges of everyday life in culturally-plural societies continue to call for a more research-based knowledge to help understand and support immigrant integration in a manner that meets the needs of individuals, groups and societies. Although Finland is only moderate on the ethnic fractionalization index, it is high on both the migrant integration and multiculturalism policy indexes. This makes Finland one of the more accepting and inclusive societies in the MIRIPS project.

\section{Context of Intercultural Relations in Finland.}

2.1 Demography. Finland has been facing challenges related to the integration of immigrants for only the last twenty years. At present, there are 289,000 foreign-born nationals in Finland (Statistics Finland, 2014) which constitutes around five per cent of the country's total population. This demographic change in Finland is a result of different processes: (1) the large-scale immigration of Russians and Russian Finns after the collapse of the Soviet Union; (2) the eastwards enlargement of the European Union (EU) resulting in noticeable, labor-driven immigration from the neighboring Estonia; and (3) the ongoing 
reception of asylum-seekers from the Horn of Africa region and the Middle East.

To add, the most common reasons for immigrating to Finland include family reunification and marriages (54\%), working (18\%), studying (10\%) and asylum seeking (10\%) (Nieminen, Sutela, \& Hannula, 2015).

Demographic, cultural and social changes related to immigration call for more research that would address ways to ensure successful integration of immigrants and positive intergroup relations in society. In the MIRIPS framework, such research also needs to better acknowledge that both integration and intergroup relations require mutual efforts of both majority group members and immigrants. To properly address the notions of mutuality and reciprocity within the context of immigrant integration, a closer merger between acculturation theory and social psychology of intergroup relations is required. Such research will fulfil the urgent need of finding measures helping to strengthen and adjust the country's multicultural integration policy to the changing context, and to prevent intergroup tensions now and in the future.

2.2 Policy. As mentioned above, the official multicultural policy of Finland fares well in international comparison. For example, from year to year, Finland is among the top countries in the MIPEX index that focuses on labor market mobility, rights to family reunion, equality issues in health care and education, political participation of immigrants, access to permanent residence and 
nationality, and measures taken against discrimination (MIPEX, 2015). However, in the aftermath of the so-called "refugee crisis" in Europe in 2015-2016, there has been considerable social and political pressure to tighten Finland's immigration policy, especially when it comes to family reunion and the rights of paperless migrants. Moreover, as pointed out by Saukkonen (2013), we should keep in mind that it is not enough to consider the degree of multiculturalism in a country solely on the basis of rules and recommendations: The grass-root level of practices and the attitudes of lay people may not be in line with official policies. He has also pointed out (Saukkonen, 2014) that in Finland, like in many other Northern European countries, integration policy has responded relatively slowly to societal changes caused by immigration, and the implementation of policy actions is suboptimal in relation to formal objectives.

\section{Evaluation of the Multiculturalism Hypothesis in Finland}

In the Finnish MIRIPS study, we examined the multiculturalism hypothesis, and did not evaluate the contact or integration hypotheses directly. We focused on the intergroup relations between majority Finns and Russian-speaking immigrants in Finland. The reason for studying this particular group of immigrants is twofold. First, Russian-speakers are the biggest immigrant group in Finland: Immigrants from Russia and former Soviet republics are the largest foreign-born group in the country (slightly over one percent of the total population; Statistics 
Finland, 2014). While the Russian immigration noticeably increased right after the collapse of the Soviet Union, it has remained relatively steady over the following years. Moreover, Russians language speakers in fact constitute one of the oldest ethnic minority groups in Finland, the settlement of which dates back to the beginning of the 19th century when Finland became a part of the Russian Empire.

Second, the relationships between Finns and Russian-speakers are characterized by historical and political antagonism that poses specific requirements for scientific research focusing on means to overcome barriers for mutual integration. Although in 1917 Finland became a sovereign state, due to the country's close proximity to the Soviet Union, Russians remained a vivid part of the Finnish history. The most important problems for the bilateral relations between the two countries involved armed conflicts during the World War II, as the result of which Finland lost some of its territories to the Soviet Union in 1945. In the post-war era, the Soviet influence over Finland became more subtle, but it significantly affected Finnish politics and trade (Allison, 1985). Therefore, the Finnish-Russian (Soviet) relations in the 20th century were rather conflictual and are most likely one of the reasons for quite strong and pervasive prejudice against immigrants from Russia and from the post-Soviet republics among Finns, and the low standing of this group in the Finnish ethnic hierarchy over the years (Jaakkola, 2005, 2009). 
To investigate the intergroup relations between Finns and Russian-speaking immigrants, we conducted four studies utilizing and broadening the methodology of the MIRIPS project. In this chapter, we summarize the results of four studies published by the first author and her colleagues (Brylka, Mähönen, \& JasinskajaLahti, 2015a; Brylka, Mähönen, \& Jasinskaja-Lahti, 2015b; Brylka, Mähönen, Schellhaas, \& Jasinskaja-Lahti, 2015; Mähönen, Brylka, \& Jasinskaja-Lahti, 2014). The four studies are: 1 . 'Threats and gains, and attitudes towards minority groups'; 2. 'Ownership of the country and mutual attitudes of majority and minority members'; 3. 'The role of ethnic superiority in outgroup attitudes and support for multiculturalism'; and 4. 'Cultural discordance and support for minority groups' collective action'.

These studies contribute to our understanding of the premises of and dynamics involved in the multiculturalism hypothesis. The second to fourth studies were also included in the doctoral dissertation in social psychology of the first author. We have looked closely at (1) social psychological outcomes of acculturation (intergroup attitudes, endorsement of multiculturalism and support for minority group's collective action) and (2) the role of identity processes and threat perceptions in shaping the aforementioned outcomes of acculturation. Thus, our four studies do not only test the social psychological processes outlined in the 
interactive acculturation model by Bourhis, Moïse, Perreault, \& Senécal (1997), but also extend our understanding of this model.

\subsection{Theoretical Issues}

In our studies of the multiculturalism hypothesis, we highlight the notions of mutuality and reciprocity as crucial for understanding intergroup relations in general and the functioning of multicultural hypothesis in particular. We see mutual efforts of majority members and immigrants to be the necessary prerequisites of promoting confidence in and feeling of security about their own cultural identities and their place in the larger society. In our studies, we aimed at bridging social psychological and acculturation theorizations which focus on the role of identities in predicting and shaping intergroup relations (see Horenczyk, Jasinskaja-Lahti, Sam, \& Vedder, 2013). Specifically, we have studied three indicators of the quality of intergroup relations that allowed us to explore the multiculturalism hypothesis among majority Finns and Russian-speaking immigrants in Finland: (i) positive intergroup attitudes (Study 1,2 and 3),; (ii) the endorsement of the multicultural ideology (Study 3); and (iii) support for collective action towards egalitarian change in society (Study 4).

These three indicators vary with the degree of engagement dedicated by an individual to promoting good quality relations with other groups in society. While 
favorable intergroup attitudes reflect relatively passive positive orientation towards outgroups, support for multiculturalism requires more active engagement in acknowledging and promoting ethno-cultural diversity. Even greater social engagement and dedication to equality of intergroup relations is needed to support collective action of the minority outgroup or one's own minority ingroup.

Therefore, examining these three indicators allows for a deeper insight into identity-related processes behind the different levels of engagement in promoting positive intergroup relations in culturally diverse societies by majority and minority group members. Next, we describe the specific theoretical models tested in each of our four studies.

\subsection{Previous Research.} Study 1: Threats and gains, and attitudes towards minority groups

The multiculturalism hypothesis proposes that feeling secure in ones ethnocultural place in society will provide a basis for accepting those who are culturally-different. In contrast, as proposes in Chapter 1, when such security is undermined or threatened, the opposite reaction will be present. Previous research has corroborated the role of perceived threats in explaining the association between strong national identification and opposition to immigration among majority group members (e.g., Bizman \& Yinon, 2001a, 2001b). In this study, we suggest that the association between high national identification and more negative attitudes toward 
immigrants may be inhibited by gains perceived to result from immigration. To test this assumption, two competitive models were examined. In the first model based on social identity theory (Tajfel \& Turner, 1979), we tested whether the perception of more gains than threats could prevent national identification from negatively impacting attitudes toward immigrants; in the second model, based on integrated threat theory (Stephan \& Stephan, 2000), we tested if the negative association between national identification and outgroup attitudes is merely due to perceiving more threats than gains resulting from immigration. In addition, we investigated whether the nature of the studied associations changed when a distinction between (1) personal versus group and (2) realistic versus symbolic threats and gains was introduced.

\section{Study 2: Ownership of the country and mutual attitudes of majority and minority members}

Intergroup relations between majority members and immigrants are often characterized by negotiations over the groups' rights, responsibilities and power to dictate rules. Recently, two interesting and useful concepts have been proposed that help us to better understand the differences in standings toward these issues: autochthony (Ceuppens \& Geschiere, 2005; Gausset, Kenrick, \& Gibb, 2011; see also Martinovic \& Verkuyten, 2013) and psychological ownership (Verkuyten, Sierksma, \& Martinovic, 2015). While autochthony refers to feelings of ownership 
derived from the belief of primary occupancy of a territory, psychological ownership of the country refers to possessive feelings held by individuals towards their country of birth (majority members) or residence (minority members) (cf. Pierce, Kostova, \& Dirks, 2001, 2003). As shown by Martinovic and Verkuyten (2013), high national identifiers claim stronger autochthony and thus also more right to regulate immigration and intergroup relations. This finding was

corroborated for psychological ownership among children whose entitlement to the territory gave them more rights to regulate the rules of playing (Verkuyten et al., 2015).

In contrast to this previous research which focused on the majority point of view only, in this study we examine whether immigrants also experience feelings of psychological ownership of the country, and whether these feelings explain the relationship between national identification and intergroup attitudes among both majority Finns and Russian immigrants.

\section{Study 3: The role of ethnic superiority in outgroup attitudes and support for multiculturalism}

Previous research among majority members has focused mainly on factors explaining negative attitudes toward immigration and immigrants, and support for multiculturalism (e.g., Hodson, Dovidio \& Esses, 2003; Verkuyten \& Martinovic, 
2006). In these studies, high national identification, especially if too narrowly and ethnically defined, was seen as one of the key elements preventing national majority groups from being more inclusive. In contrast, studies focusing on the association between ethnic identification and outgroup attitudes among minority group members and immigrants often show that high ethnic identifiers have more positive attitudes toward the majority group (e.g., Staerklé, Sidanius, Green, \& Molina, 2005) and that they more strongly endorse multiculturalism (e.g., Verkuyten \& Martinovic, 2006). However, the question remains whether all forms of ethnic identification are similarly beneficent.

In this study, we aim to identify those ethnic identity dimensions that may prevent immigrants from engaging in positive intergroup relations with the majority. Specifically, we examine the roles of the affective-cognitive and the ethnic superiority aspects of ethnic identification in outgroup attitudes towards majority Finns, and in the endorsement of multiculturalism among Russian immigrants. Ethnic superiority (an identity dimension resembling blind patriotism; Schatz, Staub, \& Lavine, 1999; Staub, 1997) and collective narcissism (Bizumic \& Duckitt, 2008; Golec de Zavala, Cichocka, Eidelson, \& Jayawickreme, 2009) are conceptualized in this study as a perception of the exaggerated worthiness of one's ethnic ingroup. We tested whether positive emotional identification with one's own ethnic group translates into more negative attitudes toward the majority group and 
less support for multiculturalism, if combined with too pronounced feelings of ethnic superiority.

\section{Study 4: Cultural discordance and support for minority groups' collective action}

Previous research strongly recommends moving toward more complex and truly reciprocal models of integration (Horenczyk et al., 2013) as envisaged by Berry (1980) and elaborated by Bourhis and his colleagues (1997). Thus, while in studies 1 to 3 we focused on the reciprocity of integration by addressing the dynamics of intergroup relations among majority Finns and Russian-speaking immigrants separately, in this study, we aim to better incorporate the idea of reciprocity at the level of measurement. Moreover, instead of focusing on intergroup attitudes, we examine support for collective action which is a more active and behavioral way of challenging intergroup inequalities than only having positive outgroup attitudes.

Thus, in study 4 we investigate the degree and the role of cultural discordance (a disagreement between majority and minority group members on the preferred degree of minority groups' cultural maintenance ;Piontkowski, Rohmann, \& Florack, 2002) in support for an egalitarian change in ethnoculturally diverse society from the perspective of both majority Finns and Russian immigrants. Specifically, we examine whether perceived cultural discordance is 
associated with support for minority group's collective action among both minority and majority group members, and whether intergroup emotions of anxiety and trust mediate this association. The association between cultural discordance and support for collective action has not been previously examined which was the first novelty of this study. The second novelty concerned examining this association also among members of the national majority group, as research on support for minority groups' collective action among majorities is rather scarce (but see Mallett, Huntsinger, Sinclair, \& Swim, 2008).

\section{Method}

\subsection{Samples}

The data for this study were collected by Professor Inga Jasinskaja-Lahti and her research team in the Department of Social Research at the Faculty of Social Sciences, the University of Helsinki. The representative sampling was conducted by the Finnish National Population Register Center. The inclusion criteria for the majority group members were Finnish as the mother tongue, being born in Finland and residing in the country at the time of the survey. The criteria for the Russian immigrants were Russian as the mother tongue, being born in the 
former Soviet Union or the Russian Federation and having moved to Finland no later than January 1, 2008.

The data were collected between June and November 2012 with the use of a postal survey. The questionnaire included the core questions of the international MIRIPS study, but also other scales needed to address the research questions posed by the Finnish research team. Participation in the study was voluntary and confidential. The response rate to the survey was $33.5 \%(n=334 ; 57 \%$ female, Mage $=46)$ for the majority and $39.0 \%(n=313 ; 77 \%$ female, Mage $=45)$ for the minority sample. The final majority and minority sub-samples used in the present study remained regionally representative. However, when compared to the initial sub-samples, in the final sub-samples there were more women (Original majority sample: $48 \%$ female; Original minority sample: $67 \%$ female) and the respondents were older than the non-respondents (Original majority sample: Mage $=41$; Original minority sample: Mage $=40$ ).

\subsection{Measures}

The four studies were developed to examine the multiculturalism hypothesis of the MIRIPS project, but also to further develop the theoretical models used to explain the dynamics involved in this multiculturalism hypothesis. To give a more social psychological insight into these issues, the original MIRIPS 
questionnaire was slightly modified to better fit the Finnish national context and complemented with some additional measures. The original MIRIPS scales used in the sub-studies were: cultural identity [14], acculturation attitudes and expectations (cultural maintenance) [16; A and B] and multicultural ideology [18]. The added scales were: psychological ownership of Finland, perceived ethnic superiority, perceived acculturation attitudes of outgroup members (cultural maintenance), perceived threats and gains resulting from immigration ${ }^{1}$, intergroup anxiety, outgroup trust, support for collective action and outgroup attitudes (eight-item scale).

Psychological ownership of Finland at the individual and group level was measured with two items adapted from the Psychological Ownership Scale of Van Dyne and Pierce (2004) originally used in the organizational context. Perceived ethnic superiority was measured with a four-item scale adapted from Roccas, Sagiv, Schwartz, Halevy, and Eidelson (2008). A three-item scale was used to assess attitudes toward the cultural maintenance of Russian immigrants from the perspective of an average outgroup member (i.e., a Russian immigrant for native Finnish participants and vice versa). Perceived threats and gains resulting from Russian immigration to Finland were measured with a twelve-item five-point

\footnotetext{
${ }^{1}$ To assess the multiculturalism hypothesis, we used the scale of perceived threats and gains. Although this scale is a conceptual opposition of the original MIRIPS security scale [15], it builds on the integrated threat theory of Stephan and Stephan (2000; see also Stephan, Renfro, \& Davis, 2008) and more closely resembles the MIRIPS "perceived consequences of immigration" sub-scale of the "attitudes towards immigration [20]" scale.
} 
bipolar scale. The definitions of threats and gains were based on the distinction made by Stephan and colleagues (2008) and the bipolar form of the scale was adapted from Schwartz (2007). The items were developed for this study to tap the degree of different types of (1) personal versus group and (2) realistic versus symbolic threats and gains perceived to result from immigration from Russia to Finland. An overall threats/gains index score, reflecting a relative difference between perceived threats and gains was computed by summing individual scores on twelve items. Corresponding index scores were also calculated for personal versus group and realistic versus symbolic threats and gains. A positive index score indicates that more gains than threats were perceived, whereas a negative index score indicates that a participant perceived more threats than gains. Intergroup anxiety was measured with a six-item measure adapted from Stephan and Stephan (1985), reflecting how participants would feel during an interpersonal interaction with outgroup members. Outgroup trust was measured with three items adapted from Paolini, Hewstone, and Cairns (2007). Outgroup attitudes were measured with an eight-item scale previously used in the present intergroup context by Jasinskaja-Lahti, Liebkind, and Solheim (2009). More information about the scales used in each sub-study can be found in the original publications.

\subsection{Statistical analysis}


Statistical analyses for all four studies were conducted with SPSS software. All hypotheses were tested with conditional process analysis (Hayes, 2013), using the PROCESS tool for SPSS. In Study 1, the hypotheses were tested with the moderation and the mediation analysis; in Study 2 and 4, the hypotheses were tested with the moderated mediation model with the group's status (majority versus minority) as the moderator; in Study 3, the moderation analysis was applied. In all Studies 1 to 4, the strength and significance of conditional and indirect effects were assessed with a non-parametric bootstrapping method using 10,000 resamples. In Study 2 and 4, the moderation of the indirect effects by group status was assessed with the test of equality of the conditional indirect effects between the groups called the index of moderated mediation (see Hayes, 2015). All regression coefficients and the indirect effects are reported in an unstandardized form $(B)$. The results of the simple slopes analysis are presented as standardized betas $(\beta)$.

\section{Results}

\subsection{Study 1}

The aim of Study 1 was to clarify the nature of the relationship between national identification of majority Finns, their joint perception of threats and gains resulting from Russian immigration to Finland, and attitudes towards Russianspeaking immigrants. Specifically, it was examined whether the joint perception of 
threats and gains resulting from immigration moderated or mediated the relationship between national identification and outgroup attitudes. It was also examined whether introducing the distinction between personal versus group, and realistic versus symbolic threats and gains added to our understanding of the role of perceived threats and gains in the investigated relationship.

The testing of the proposed moderation effect has shown that there was no interaction between national identification and the perception of threats and gains resulting from Russian immigration. Thus, when participants identified more strongly as Finns it was always linked to more negative attitudes towards Russianspeaking immigrants, regardless of whether the participants perceived more or less threats in relation to gains. As regards the testing of mediation (see Figure 1), the results showed that with increasing national identification of majority Finns, the perception of threats over gains resulting from Russian immigration to Finland was also stronger. This perception, in turn, was further associated with more negative attitudes towards Russian-speaking immigrants. Therefore, with stronger national identification, majority Finns tend to perceive more threats than gains to result from Russian immigration, and this translates into more negative attitudes towards Russian-speakers residing in the country. This pattern of results was present regardless of whether different types of threats and gains were examined jointly or 
whether they were divided into personal versus group, or realistic versus symbolic threats and gains.

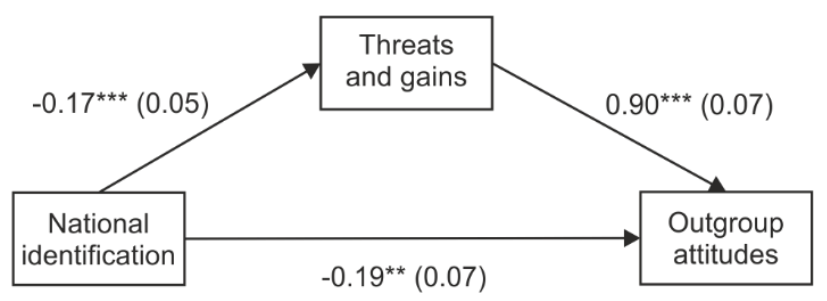

Figure 1. Predictors of the majority members' attitudes towards Russian-speaking immigrants in Finland $(N=335)$ : Mediation model

\subsection{Study 2}

In Study 2, we examined whether psychological ownership of a country mediates the association between national identification and mutual attitudes among majority Finns and Russian-speaking immigrants in Finland.

The results show (see Table 1) that when majority members identified more strongly as Finns and Russian-speaking immigrants identified more strongly with Finnish society, they both felt stronger psychological ownership of Finland. However, while this stronger ownership of Finland was linked to more negative attitudes towards Russian-speaking immigrants among majority Finns, it was linked to more positive attitudes towards majority Finns among immigrants. 
Table 1. Bootstrapped Indirect Effects of National Identification on Outgroup Attitudes via Psychological Ownership of Finland for Finns $(n=334)$ and Russian-Speaking Immigrants $(n=313)$

\begin{tabular}{lcrrr}
\hline & \multicolumn{4}{c}{ Psychological ownership } \\
\cline { 2 - 5 } Group membership & $B$ & $S E$ & $L L C I$ & $U L C I$ \\
\hline Finns & $-0.20^{*}$ & 0.04 & -0.323 & -0.094 \\
Immigrants & $0.05^{*}$ & 0.02 & 0.016 & 0.087 \\
\hline
\end{tabular}

Note. ${ }^{*}$ At least $p<.05$. LL CI and UP CI = lower and upper level of the bias corrected confidence intervals for $\alpha=.05$.

\subsection{Study 3}

The aim of Study 3 was to investigate the role of perceived ethnic superiority of the ingroup in Russian-speaking immigrants' attitudes towards majority Finns and in their support for multiculturalism. Specifically, we examined whether perceived ethnic superiority of the ingroup moderated the association between the affective-cognitive aspect of ethnic identification and attitudes towards majority Finns and support for multiculturalism, respectively.

The obtained (Table 2) results show that while the strength of ethnic identification was not associated with more negative attitudes towards majority 
Finns, feelings of ethnic superiority of Russians were associated with more negative outgroup attitudes. As regards the relationship between ethnic identification and support for multiculturalism, stronger ethnic identification was linked to stronger support for multiculturalism only among those immigrants who did not have strong feelings of ethnic superiority over other ethno-cultural groups in society.

Table 2. Regression Analysis on the Predictors of Outgroup Attitudes and Support for Multiculturalism Among Russian-Speaking Immigrants $(N=312)$

\begin{tabular}{|c|c|c|c|c|}
\hline & \multicolumn{2}{|c|}{$\begin{array}{l}\text { Outgroup } \\
\text { attitudes } \\
(\mathrm{Y} 1)\end{array}$} & \multicolumn{2}{|c|}{$\begin{array}{c}\text { Multicultural } \\
\text { ideology } \\
\text { (Y2)ticulturalism } \\
\text { (Y2) }\end{array}$} \\
\hline & B & $S E$ & B & $S E$ \\
\hline Constant & $4.29 * *$ & 0.07 & $1.41^{* *}$ & 0.38 \\
\hline $\operatorname{Sex}(0=$ male $)$ & 0.06 & 0.07 & $0.21 *$ & 0.07 \\
\hline Age & 0.00 & 0.00 & 0.00 & 0.00 \\
\hline Years of education & 0.01 & 0.01 & 0.01 & 0.01 \\
\hline $\begin{array}{l}\text { Ethnicity }(0= \\
\text { Russian) }\end{array}$ & 0.09 & 0.06 & 0.08 & 0.07 \\
\hline Cultural identity (CI) & -0.02 & 0.03 & $0.44 * *$ & 0.08 \\
\hline $\begin{array}{l}\text { Perceived superiority } \\
\text { (PS) }\end{array}$ & - & 0.04 & $0.43^{* *}$ & 0.13 \\
\hline CI $x$ PS & 0.01 & 0.03 & - & 0.03 \\
\hline
\end{tabular}

Note. ${ }^{*} p<.01 .{ }^{* *} p \leq .001$. 


\subsection{Study 4}

Study 4 investigated the previously unexplored association between perceived cultural discordance and support for the minority group's collective action, and the role of two affective mediators - intergroup anxiety and outgroup trust — in this relationship among both majority Finns and Russian-speaking immigrants.

The findings show (see Table 3 ) that when the association between perceived cultural discordance and support for collective action is analyzed, group status is an important moderator to be considered. Among majority Finns, those participants who perceived stronger cultural discordance were more negatively oriented towards the collective action of Russian-speaking immigrants. Besides this direct relationship, perceived cultural discordance was associated with support for the minority group's collective action also indirectly, through intergroup emotions of intergroup anxiety and outgroup trusts. Specifically, those Finns who perceived cultural discordance experienced stronger intergroup anxiety and trusted the outgroup less, which in turn was reflected in less support for the collective action of Russian-speaking immigrants. 
Among Russian-speaking immigrants, as expected based on the previous results (Barlow, Sibley, \& Hornsey, 2012; Rohmann, Florack, \& Piontkowski, 2006), intergroup anxiety did not play any role in the association between perceived cultural discordance and support for the ingroup's collective action. However, those Russian-speaking immigrants who perceived stronger cultural discordance felt more trust towards majority Finns and they, in turn, supported collective action of the ingroup more firmly.

Table 3. Bootstrapped Indirect Effects of Cultural Discordance on Support for Collective Action via Intergroup Anxiety and Outgroup Trust for Finns $(n=274)$ and Russian-Speaking Immigrants $(n=228)$

\begin{tabular}{|c|c|c|c|c|c|c|c|c|}
\hline \multirow[b]{2}{*}{$\begin{array}{l}\text { Group } \\
\text { membership }\end{array}$} & \multicolumn{4}{|c|}{ Intergroup anxiety } & \multicolumn{4}{|c|}{ Outgroup trust } \\
\hline & $B$ & $S E$ & $\begin{array}{l}L L \\
C I\end{array}$ & $\begin{array}{l}U L \\
C I\end{array}$ & $B$ & $S E$ & $\begin{array}{l}L L \\
C I\end{array}$ & $U P C I$ \\
\hline Finns & $\begin{array}{l}- \\
0.14^{*}\end{array}$ & 0.04 & 0.219 & $\begin{array}{l}- \\
0.075\end{array}$ & $\begin{array}{l}- \\
0.13^{*}\end{array}$ & 0.03 & 0.202 & -0.073 \\
\hline Immigrants & 0.02 & 0.02 & 0.011 & 0.069 & $0.04^{*}$ & 0.03 & 0.001 & 0.112 \\
\hline
\end{tabular}

Note. ${ }^{*}$ At least $p<.05$. LL CI and UP CI = lower and upper level of the bias corrected confidence intervals for $\alpha=.05$. 


\section{Discussion and Conclusions}

During the last decades have witnessed a growing trend in theory and research on acculturation and immigrant integration which lays emphasis on the context and mutuality of the acculturation process (e.g., Horenczyk et al., 2013). What is still lacking, however, are the attempts to overcome the barriers of concepts and models traditionally used or isolated from each other, and to suggest new and fresh ways to show and study the nuances of intergroup relations as experienced in every day intergroup interactions. In this chapter, we have presented four studies, which show how identity is strategically used to monitor intergroup relations by both majority and minority group members. The results show that both parties involved in intergroup interactions are sensitive to each other's claims, and when these claims are defined too exclusively or provocatively, ingroup identification rather undermines than supports positive intergroup relations in society. Altogether, our results support the multiculturalism hypothesis stating that when individuals feel secure about their own cultural identities, different groups are more positive toward each other but when identities are threatened, mutual hostility occurs.

In our four studies we examined the three pillars of positive intergroup relations that differ in the degree of engagement in promoting positive intergroup 
relations in diverse societies: intergroup attitudes, the endorsement of multiculturalism and support for collective action towards egalitarian change in society.

Positive intergroup attitudes. At the primary level of engagement reflected in intergroup attitudes, our studies make three important contributions. The first contribution demonstrates that threats and gains perceived to result from immigration mediate but do not moderate the association between ingroup identification and attitudes towards Russian-speaking immigrants among majority Finns (Study 1). In line with previous theorizations (Stephan \& Stephan, 2000) and results (e.g., Aberson \& Gaffney, 2009; Stephan et al., 2002), stronger Finnish national identification was associated with less favorable attitudes towards Russian-speaking immigrants due to stronger perceptions of threats over gains. Interestingly, however, realistic threats and gains played a much more significant role than symbolic threats and gains. This finding suggests that in a relatively young immigration contexts like Finland, threats (and gains) related to society's economy and security may be more important for intergroup relations than threats to the culture and way of life. Overall, the finding showing that different threats to the identity of the majority group result in more negative attitudes towards minority groups which are seen as the source of these threats supports the multiculturalism hypothesis. 
We also identified a new social psychological mechanism explaining the relationship between national identification and intergroup attitudes among both majority and minority members, namely psychological ownership of a country (Study 2). While among majority Finns, psychological ownership of Finland had an exclusionary character, it was inclusionary among Russian-speaking immigrants. Specifically, among majority Finns, psychological ownership of Finland reinforced by national identification, elicited more negative attitudes towards immigrants. This negative indirect effect may derive from rather essentialist representations of Finnishness (Varjonen, Arnold, \& Jasinskaja-Lahti, 2013) which anchor Finnish national belonging in Finnish bloodline and linguistic heritage, and exclude immigrants from the national ingroup. In contrast, among immigrants, psychological ownership of Finland was reinforced by identification with Finnish society and further linked to more positive attitudes towards majority Finns, who most likely were perceived by the immigrants as members of the common national ingroup. These findings show that among immigrants, both national identification and psychological ownership of Finland operate at the superordinate level of identification, in line with the common ingroup identity model (Gaertner \& Dovidio, 2000).

The third contribution concerns the role of perceived ethnic superiority of the ingroup in the association between the affective-cognitive aspect of 
immigrants' ethnic identification and attitudes towards the national majority group (Study 3). The findings showed that perceived ethnic superiority of one's own minority group was associated with less positive attitudes towards majority Finns among Russian-speaking immigrants. Perceived ethnic superiority, however, did not moderate the relationship between affective-cognitive aspects of ethnic identification and outgroup attitudes. These results show that the mere perception of ethnic superiority, which is likely to be a reactive result of perceived discrimination towards one's own minority group, is detrimental for attitudes towards the national majority. Thus, the last two contributions again support the multiculturalism hypothesis linking the security of identities with more favorable outgroup attitudes.

Support for multiculturalism. With respect to the engagement of individuals in a more active promotion of cultural diversity in the country, that is endorsing multiculturalism, our studies shed more light on the conditions under which immigrants support this ideology (Study 3). Previous research among minority members has shown that even high ethnic identification in terms of emotional and cognitive attachment to the ethnic ingroup is not detrimental to intergroup relations and it supports the endorsement of multiculturalism. However, as the fourth contribution of our present research we found that when immigrants perceive their ethnic ingroup as superior to other groups in society, the positive association 
between ethnic identification and support for multiculturalism disappears. Thus, this finding highlights the need of acknowledging the multidimensionality of ethnic identification when intergroup attitudes in diverse societies are investigated. As indicated by previous theorizations (e.g., Roccas et al., 2008) and the multiculturalism hypothesis, the obtained results corroborate that while some (secure) aspects of ethnic identification are constructive and contribute to more positive intergroup relations, other (non-secure) dimensions of ethnic identification do not necessarily support ethno-cultural diversity.

Support for collective action. Concerning the most active and engaged form of support for ethno-cultural diversity (that is support for the minority group's collective action), our research broadens the understanding of this form of intergroup solidarity and its underlying processes among majority group members and immigrants (Study 4). For the first time we have shown that stronger perception that Russian-speaking immigrants wish to maintain more of their heritage culture than the majority group approves is associated with stronger intergroup anxiety and lower trust towards these immigrants among majority Finns. These two intergroup emotions are, in turn, linked to lower support for Russian-speaking immigrants' collective struggle towards more social equality and equal participation in society. For Russian-speaking immigrants, stronger perception that majority Finns allow to preserve Russian culture to a lesser extent 
than the immigrants wish is linked to lower trust towards the majority group, which in turn is associated with stronger support for the ingroup's collective action. Also the sole perception of cultural discordance directly triggers support for the ingroup's collective action. Therefore, these findings constitute the fifth novelty of the present research and highlight the previously signalized (e.g., van Zomeren, Leach, \& Spears, 2012) importance of emotional processes in intergroup relations. At the same time, these findings are very strongly supporting the multiculturalism hypothesis by showing the importance of secure identities in intergroup solidarity.

The presented results corroborate the important roles of identity-related determinants and the security of majority and minority identities in intergroup relations in plural societies. They also offer practical implications for improving intergroup relations in terms of guidelines for practices that would promote social equality and facilitate accommodation of immigrants into society already upon their arrival. The results point at the need to prevent or change negative attitudes of majority group members and immigrants towards each other. This could be done, for instance, by promoting among the national majority a more inclusive, citizenship-based understanding of national identification (Study 2) that would result in more positive intergroup attitudes among majority and minority members. 
Moreover, secure ethnic identification should be promoted and the possible perception of one's minority ingroup being superior to other groups in society (ethnic superiority) should be discouraged among those immigrants who wish to maintain their cultural heritage in the host country (Study 3 ). The promotion of constructive and secure dimensions of ethnic identification and positive, nonexclusive pride over one's ethno-cultural background should contribute to more favorable intergroup attitudes and stronger support for multiculturalism among majority and minority groups alike. In general, intergroup respect should be promoted so that no group in society would feel that its cultural background and identity are threatened; different groups should also feel that they have a confident sense of place in the plural society (as originally proposed in the multiculturalism hypothesis by Berry, Taylor, \& Kalin, 1977). In such a case, in line with the multiculturalism hypothesis, there would be no need for exclusive intergroup attitudes and excessive bolstering of one's ingroup's value.

With growing ethno-cultural diversity, more equal social relationships between all groups in society should be endorsed by, for example, supporting the collective struggle of immigrants towards equal rights and social participation. As shown in Study 4, it is especially important to promote secure identities among members of majority and minority groups as they are likely to result in lower 
intergroup anxiety and alleviated outgroup trust, both of which play a crucial role in support for intergroup solidarity (see e.g., Pettigrew \& Tropp, 2006).

Finally, our study accentuates the reciprocity of intergroup relations, thus, dividing the responsibility for immigrants' socio-cultural adaptation and integration to the host society between majority members and immigrants. Despite the fact that the national majority group has always more power in shaping the social context of intergroup relations than minority groups (see Berry, 2001; Bourhis et al., 1997; Navas et al., 2005), it is important that both majority group and immigrants become more conscious of their joint contribution to the degree of inclusiveness and peacefulness of the intergroup context.

\section{References}

Aberson, C. L. \& Gaffney, A. M. (2009). An integrated threat model of explicit and implicit attitudes. European Journal of Social Psychology, 39, 808830.

Allison, R. (1985). Finland's relations with the Soviet Union, 1944-84. London, United Kingdom: Macmillan.

Barlow, F. K., Sibley, C. G., \& Hornsey, M. J. (2012). Rejection as a call to arms: Inter-racial hostility and support for political action as outcomes of race- 
based rejection in majority and minority groups. British Journal of Social Psychology, 51, 167-177.

Berry, J. W. (2001). A psychology of immigration. Journal of Social Issues, 57, $615-631$.

Berry, J. W., Taylor, D. M., \& Kalin, R. (1977). Multiculturalism and ethnic attitudes in Canada. Ottawa, Canada: Minister of State for Multiculturalism.

Bizman, A., \& Yinon, Y. (2001a). Intergroup and interpersonal threats as determinants of prejudice: the moderating role of in-group identification. Basic and Applied Social Psychology, 23, 191-196.

Bizman, A., \& Yinon, Y. (2001b). Perceived threat and Israeli Jews' evaluations of Russian immigrants: the moderating role of Jewish and Israeli identity. International Journal of Intercultural Relations, 25, 691-704.

Bizumic, B., \& Duckitt, J. (2008). "My group is not worthy of me": Narcissism and ethnocentrism. Political Psychology, 29, 437-453.

Bourhis, R. Y., Moïse, L. C., Perreault, S., \& Senécal, S. (1997). Towards an interactive acculturation model: A social psychological approach. International Journal of Psychology, 32, 369-386.

Brylka, A., Mähönen, T. A., \& Jasinskaja-Lahti, I. (2015a). National identification and attitudes towards Russian immigrants in Finland: Investigating the role 
of perceived threats and gains. Scandinavian Journal of Psychology, 56, $670-677$.

Brylka, A., Mähönen, T. A., \& Jasinskaja-Lahti, I. (2015b). National identification and intergroup attitudes among members of the national majority and immigrants: Preliminary evidence for the mediational role of psychological ownership of a country. Journal of Social and Political Psychology, 3, 2445.

Brylka, A., Mähönen, T. A., Schellhaas, F. M. H., \& Jasinskaja-Lahti, I. (2015). From cultural discordance to support for collective action: The roles of intergroup anxiety, trust and group status. Journal of Cross-Cultural Psychology, 46, 897-915.

Ceuppens, B., \& Geschiere, P. (2005). Autochthony: Local or global? New modes in the struggle over citizenship and belonging in Africa and Europe. Annual Review of Anthropology, 34, 385-407.

Gaertner, S. L., \& Dovidio, J. F. (2000). Reducing intergroup bias: The common ingroup identity model. Philadelphia, PA: Psychology Press.

Gausset, Q., Kenrick, J., \& Gibb, R. (2011). Indigeneity and autochthony: A couple of false twins? Social Anthropology, 19, 135-142. 
Golec de Zavala, A., Cichocka, A., Eidelson, R., \& Jayawickreme, N. (2009). Collective narcissism and its social consequences. Journal of Personality and Social Psychology, 97, 1074-1096.

Hayes, A. F. (2013). Introduction to mediation, moderation, and conditional process analysis: A regression-based approach. New York, NY: The Guilford Press.

Hayes, A. F. (2015). An index and test of linear moderated mediation. Multivariate Behavioral Research, 50, 1-22.

Hodson, G., Dovidio, J. F., \& Esses, V. M. (2003). Ingroup identification as a moderator of positive-negative asymmetry in social discrimination. European Journal of Social Psychology, 33, 215-233.

Horenczyk, G., Jasinskaja-Lahti, I., Sam, D. L., \& Vedder, P. (2013). Mutuality in acculturation. Zeitschrift für Psychologie, 221(4), 205-213.

Jaakkola, M. (2005). Suomalaisten suhtautuminen maahanmuuttajiin vuosina 1987-2003 [Finns' attitudes towards immigrants in years 1987-2007]. Helsinki, Finland: Ministry of Labour.

Jaakkola, M. (2009). Maahanmuuttajat suomalaisten näkökulmasta: Asennemuutokset 1987-2007 [Immigrants from the perspective of Finns: Change in attitudes 1987-2007]. Helsinki, Finland: City of Helsinki Information Center. 
Jasinskaja-Lahti, I., Liebkind, K., \& Solheim, E. (2009). To identify or not to identify? National disidentification as an alternative reaction to perceived ethnic discrimination. Applied Psychology, 58(1), 105-128.

Mähönen, T. A., Brylka, A., \& Jasinskaja-Lahti, I. (2014). Perceived ethnic superiority and immigrants' attitudes towards multiculturalism and the national majority. International Journal of Psychology, 49, 318-322.

Mallett, R. K., Huntsinger, J. R., Sinclair, S., \& Swim, J. K. (2008). Seeing through their eyes: When majority group members take collective action on behalf of an outgroup. Group Processes and Intergroup Relations, 11, 451-470.

Martinovic, B., \& Verkuyten, M. (2013).'We were here first, so we determine the rules of the game': Autochthony and prejudice towards out-groups. European Journal of Social Psychology, 43, 637-647.

Migrants Integration Policy Index MIPEX (2015). Retrieved from http://www.mipex.eu/

Navas, M., García, M., Sánchez, J., Rojas, A. J., Pumares, P., \& Fernandez, J. S. (2005). Relative acculturation extended model (RAEM): New contributions with regard to the study of acculturation. International Journal of Intercultural Relations, 29, 21-37. 
Nieminen, T., Sutela, H., \& Hannula, U. (2015). Ulkomaista syntyperää olevien työ ja hyvinvointi Suomessa 2014 [Work and well-being of foreigners in Finland 2014]. Helsinki, Finland: Statistics Finland.

Paolini, S., Hewstone, M., \& Cairns, E. (2007). Direct and indirect intergroup friendship effects: Testing the moderating role of the affective and cognitive bases of prejudice. Personality and Social Psychology Bulletin, $33,1406-1420$.

Pettigrew, T. F., \& Tropp, L. R. (2006). A meta-analytic test of intergroup contact theory. Journal of Personality and Social Psychology, 90, 751-783.

Pierce, J. L., Kostova, T., \& Dirks, K. T. (2001). Toward a theory of psychological ownership in organizations. Academy of Management Review, 26, 298-310.

Pierce, J. L., Kostova, T., \& Dirks, K. T. (2003). The state of psychological ownership: Integrating and extending a century of research. Review of General Psychology, 7, 84-107.

Piontkowski, U., Rohmann, A., \& Florack, A. (2002). Concordance of acculturation attitudes and perceived threat. Group Processes and Intergroup Relations, 5, 221-232.

Roccas, S., Sagiv, L., Schwartz, S., Halevy, N., \& Eidelson, R. (2008). Toward a unifying model of identification with groups: Integrating theoretical perspectives. Personality and Social Psychology Review, 12, 280-306. 
Rohmann, A., Florack, A., \& Piontkowski, U. (2006). The role of discordant acculturation attitudes in perceived threat: An analysis of host and immigrant attitudes in Germany. International Journal of Intercultural Relations, 30, 683-702.

Saukkonen, P. (2013). Erilaisuuksien Suomi [Finland of diversities]. Helsinki, Finland: Gaudeamus.

Saukkonen, P. (2014). Multiculturalism and cultural policy in Northern Europe. The Nordic Journal of Cultural Policy/Nordisk Kulturpolitisk Tidsskrift, 16(02), 178-200.

Schatz, R. T., Staub, E., \& Lavine, H. (1999). On the varieties of national attachment: Blind versus constructive patriotism. Political Psychology, 20, $151-174$.

Schwartz, S. (2007). Universalism, values, and the inclusiveness of our moral universe. Journal of Cross-Cultural Psychology, 38, 711-728.

Staerklé, C., Sidanius, J., Green, E. G. T., \& Molina, L. (2005). Ethnic minoritymajority asymmetry and attitudes towards immigrants across 11 nations. Psicologia Politica, 30, 7-26.

Statistics Finland (2014). Foreign-language speakers account for 90 per cent of the population growth in 2013. Retrieved from 


\section{http://tilastokeskus.fi/til/vaerak/2013/vaerak_2013_2014-03-}

$\underline{21 \text { tie_001_en.html }}$

Stephan, W. G., \& Stephan, C. W. (1985). Intergroup anxiety. Journal of Social Issues, 41, 157-175.

Stephan, W. G., \& Stephan, C. W. (2000). An integrated threat theory of prejudice. In S. Oskamp (Ed.), Reducing prejudice and discrimination. The Claremont Symposium on applied social psychology (pp. 23-45). Mahwah, NJ: Lawrence Erlbaum Associates, Inc.

Stephan, W. G., Boniecki, K. A., Ybarra, O., Bettencourt, A., Ervin, K. S., Jackson, L. A., McNatt, P. S. \& Renfro, C. L. (2002). The role of threats in the racial attitudes of Blacks and Whites. Personality and Social Psychology Bulletin, 28, 1242-1254.

Stephan, W. G., Renfro, C. L., \& Davis, M. D. (2008). The role of threat in intergroup relations. In U. Wagner, L. R. Tropp, G. Finchilescu, \& C. Tredoux (Eds.), Improving intergroup relations. Building on the legacy of Thomas F. Pettigrew (pp. 55-72). Malden, MA: Blackwell.

Tajfel, H., \& Turner, J. (1979). An integrative theory of intergroup conflict. In M.

A. Hogg \& D. Abrams (Eds.), Intergroup relations (pp. 94-109).

Philadelphia, PA: Psychology Press. 
Van Dyne, L., \& Pierce, J. L. (2004). Psychological ownership and feelings of possession: Three field studies predicting employee attitudes and organizational citizenship behavior. Journal of Organizational Behavior, $25,439-459$.

van Zomeren, M., Leach, C. W., \& Spears, R. (2012). Protesters as "passionate economists": A dynamic dual pathway model of approach coping with collective action. Personality and Social Psychology Review, 16, 180-199.

Varjonen, S., Arnold, L., \& Jasinskaja-Lahti, I. (2013). 'We're Finns here, and Russians there': A longitudinal study on ethnic identity construction in the context of ethnic migration. Discourse and Society, 24, 110-134.

Verkuyten, M., \& Martinovic, B. (2006). Understanding multicultural attitudes: The role of group status, identification, friendships, and justifying ideologies. International Journal of Intercultural Relations, 30, 1-18.

Verkuyten, M., Sierksma, J., \& Martinovic, B. (2015). First arrival and collective land ownership: How children reason about who owns the land. Social Development, 24, 868-882. 